\title{
ACTIVE INGREDIENTS OF MOUTHWASHES
}

\author{
EWA OLEJNIK and JOLANTA SZYMAŃSKA* \\ Department of Integrated Paediatric Dentistry, Chair of Integrated Dentistry, \\ Medical University of Lublin, Poland
}

\begin{abstract}
The principal method of preventing the formation of dental plaque (a cause of numerous oral diseases, such as dental caries, gingivitis, periodontitis, and oral mucositis) is its mechanical removal by brushing with a toothbrush and toothpaste. By reaching spaces inaccessible to the bristles of a toothbrush, mouthwashes are an important adjunct to brushing and increase the efficacy of daily mouth hygiene routines. Mouthwash ingredients demonstrate antibacterial activity, reduce dental plaque deposition and are used both in prophylaxis and in therapy. The agents most frequently found in mouthwashes include fluorine, chlorhexidine, cetylpyridinium chloride, sanguinarine, triclosan, povidone-iodine, hydrogen peroxide, ethyl alcohol, and others described in the paper.
\end{abstract}

Keywords: oral hygiene, mouthwashes, dental plaque, prevention, dental caries, periodontitis

As a bacterial biofilm, dental plaque causes numerous diseases of the oral cavity: dental caries, gingivitis, periodontal disease, and oral mucositis (1). Dental plaque consists of bacterial masses deposited on tooth surfaces and it usually occurs at the gingival margin: supragingival and subgingival, and in the interproximal areas (2).

Mechanical removal of plaque by brushing the teeth with a toothbrush and toothpaste is the principal method of preventing biofilm formation. Other means of maintaining correct oral hygiene include the use of dental floss, toothpicks, tongue cleaners, mouthwashes, and irrigators $(3,4)$. By reaching interdental spaces, where most bacteria and dental plaque accumulate, they improve the effectiveness of hygienic procedures (5). Regular mouth rinsing after toothbrushing should be performed once or twice daily.

Mouthwashes are usually a mixture of antimicrobial agents with water or alcohol and contain additional ingredients, such as surface-active agents and flavor compounds. The most frequently used antimicrobial agents include chlorhexidine (CHX), cetylpyridinium chloride (CPC), delmopinol, hexetidine, metal ions $\mathrm{Cu}^{2+}, \mathrm{Sn}^{2+}$, and $\mathrm{Zn}^{+}$, triclosan, xylitol, and essential oils (OE).

Mouthwashes are the simplest vehicles for antibacterial agents and substances impeding the growth of dental plaque.

\footnotetext{
* Corresponding author: e-mail: szymanska.polska@gmail.com
}

Mouthwashes are expected to:

- have acceptable taste,

- be safe as regards their effect on dental tissues and oral mucosa,

- show efficacy in removing microbes from the spaces in the oral cavity that are inaccessible to the bristles of a toothbrush, dental floss, and toothpicks,

- have anti-caries and anti-inflammatory effects,

- be effective in reducing mouth dryness and halitosis,

- thoroughly clean the areas around orthodontic appliances and prosthetic restorations,

- diminish teeth hypersensitivity,

- have broad antimicrobial activity spectrum,

- cause no adverse effects,

- be chemically stable,

- persist in the mouth for long periods of time (615).

Particular indications for the use of mouthwashes include:

- medium and high-intensity caries,

- postoperative prophylactics in dental surgery and periodontology,

- the need to improve oral hygiene in physically and mentally disabled patients in whom toothbrushing is not fully effective, 
- acute and chronic inflammatory conditions of the gums and periodontium,

- prevention of periodontitis and oral mucositis in immunocompromised patients,

- dry mouth (xerostomia),

- halitosis,

- anti-caries prophylactics in patients treated with radiotherapy and chemotherapy,

- prevention of post-implantation complications and in cases of periimplantitis,

- the use of orthodontic appliances and prosthetic restorations,

- teeth hypersensitivity $(5,11-13,16-20)$.

Mouthwashes recommended for direct use contain, among others:

- fluoride,

- chlorhexidine,

- cetylpyridinium,

- sanguinarine,

- triclosan,

- hydrogen peroxide,

- povidone-iodine,

- delmopinol hydrochloride,

- octapinol,

- hexetidine,

- ethyl alcohol,

- substances of natural origin;

The latter include:

- pomegranate (Punica granatum),

- common guava (Psidium guajava),

- nimtree (Azadirachta indica),

- propolis,

- holy basil (Ocimum sanctum),

- green tea (Camellia sinensis),

- large cranberry (Vaccinium macrocarpon),

- multicomponent products, e.g., Dentosept by Phyto Pharm.

\section{Fluoride}

Fluoride is an element that can be found in the human body: teeth, bones, thyroid gland, and skin (21). Fluoride compounds are added to most toothpastes, mouthwashes, dental flosses, and chewing gums. The principal activity of fluoride is anti-cariogenic (22). Fluoride compounds used in dentistry include sodium fluoride $(\mathrm{NaF})$, stannous fluoride $\left(\mathrm{SnF}_{2}\right)$, sodium monofluorophosphate $\left(\mathrm{Na}_{2} \mathrm{PFO}_{3}\right)$, and amine fluorides $\left(\mathrm{C}_{27} \mathrm{H}_{60} \mathrm{~F}_{2} \mathrm{~N}_{2} \mathrm{O}_{3}\right)$.

In the process of enamel formation (amelogenesis), fluoride exerts an influence on the production of hydroxyapatite and is a component of fluorapatite, generated as a result of substituting a hydrogen ion in the hydroxyapatite particle with a fluorine ion. Fluorapatite is more resistant to acids produced by cariogenic bacteria. The principal action of fluoride consists in reducing enamel demineralization and promoting remineralization of the damaged surfaces of dental hard tissues (6). Due to the strong chemical affinity to calcium ions, after using fluoride compounds, calcium fluoride is generated. At a lowered $\mathrm{pH}$ in the oral cavity, calcium fluoride releases negatively charged ions of fluorine which adhere to enamel micro-lesions, producing enamel fluorapatites. Fluorapatite is more resistant to acid produced by cariogenic bacteria metabolism, as well as acids contained in food and drink. The critical $\mathrm{pH}$ of a solution that dissolves fluorapatite is 4.5 (2325). In addition, fluoride diminishes bacterial plaque formation and reduces cariogenic bacterial count (Streptococcus mutans, Lactobacillus acidophilus), as well as affects bacterial cell metabolism, modifying the processing of carbohydrates in the cells of cariogenic bacteria by inhibiting enolase. Fluorine ions bind to magnesium ions in enolase particles, thus inhibiting its action (23).

Most mouthwashes contain fluoride. The recommended concentration of fluoride in daily-use mouthwashes is $0.05 \%$. In mouthwashes used once a week, the recommended fluoride concentration is $0.2 \%$.

\section{Chlorhexidine}

Chlorhexidine (CHX) $\left(\mathrm{C}_{22} \mathrm{H}_{30} \mathrm{Cl}_{2} \mathrm{~N}_{10}\right)$, an antiseptic agent broadly used in contemporary medicine, was discovered in England in the 1950s. Initially, it was used as an antiseptic for skin disinfection. At present, it is considered one of the most effective substances reducing the accumulation of bacterial plaque on teeth surfaces and reducing inflammations of gums and the periodontium (26). Chemically, chlorhexidine is a cationic biguanide. It has a broad spectrum of antibacterial activity against Gram-positive and Gram-negative microorganisms. In addition, chlorhexidine is active against viruses and some protozoa. CHX is also effective in reducing Candida fungi levels (27).

CHX is broadly used in dentistry. It is an active substance in mouthwashes, toothpastes, gels, concentrated root canal rinses and gutta percha points, as well as varnishes. In mouthwashes, the concentration of chlorhexidine is $0.1-0.2 \%$. In periodontology, used as a medication, it reduces inflammation of the periodontium. In endodontics, chlorhexidine solutions are used to disinfect infected tooth cavities, while gutta percha points with $\mathrm{CHX}$ are effective as temporary canal fillings. $5 \%$ chlorhexidine 
contained in the points is gradually released into an infected canal, which increases the probability of successful endodontic treatment. Chlorhexidine is the only chemical compound used in dentistry that destroys bacteria Enterococcus faecalis responsible for complications in endodontic treatment.

In cases of intense caries, the use of CHX-containing varnishes, e.g., Cervitec ${ }^{\circledR}$ by Ivoclar Vivadent, is recommended to significantly reduce the emergence of new caries foci (28). In addition, $0.2 \%$ chlorhexidine is considered the gold standard in fighting the bacteria present in the mouth $(29,30)$. The negatively charged surfaces of teeth, mucosa, and mucin present in the saliva attract positively charged particles of chlorhexidine. As a result, CHX persists in the saliva and on the surfaces of teeth and mucosa for about 6-8 $\mathrm{h}$ (31). If a chlorhexidine-containing mouthwash is used before sleep, this biguanide can stay in the saliva even up to $12 \mathrm{~h}$. CHX is released gradually, showing an antibacterial effect. Remaining in the oral cavity for many hours, chlorhexidine reduces adherence of bacteria to the surface of teeth and mucosa (27). CHX does not cause resistance in bacteria exposed to this compound (6). The cationic groups of chlorhexidine bind with sulfates, phosphates, and carboxyl groups on the surfaces of bacteria. Lower-concentration chlorhexidine solutions have bacteriostatic activity, decreasing transport and membrane permeability and thus inhibiting the growth of bacterial cells (32). In higher concentrations, chlorhexidine penetrates through bacterial cell walls, causing coagulation of cytoplasm and having a bactericidal effect (29).

Despite numerous advantages, chlorhexidine causes also adverse effects, including

- yellowish-brown discoloration of teeth, mucosa, dental fillings, and prosthetic restorations (if used for more than 3 weeks),

- black hairy tongue (a condition of the tongue surface),

- taste alteration,

- increased deposition of dental calculus,

- hypersensitivity and burning sensation in the oral mucosa,

- parotid gland swelling.

The mentioned conditions recede when the use of chlorhexidine-containing products is discontinued (33).

\section{Cetylpyridinium chloride}

Cetylpyridinium chloride (CPC) $\left(\mathrm{C}_{21} \mathrm{H}_{38} \mathrm{CIN}\right)$ is a cationic quaternary compound. Thanks to its antibacterial properties, it is a broadly used ingredient of mouthwashes (34). It binds to the negatively charged dental plaque and reduces the surface tension of the bacterial cell membrane, causing disruption of the membrane and destruction of the bacterial cell. CPC also affects bacterial metabolism and significantly reduces the adhesion of microorganisms to teeth surfaces (35). It is well and quickly adsorbed by teeth surfaces, which inhibits the adhesion of bacteria to the hard tissue of the tooth and reduces plaque build-up. CPC is the most frequently used, apart from fluoride compounds, ingredient of mouthwashes (6).

The characteristics of cetylpyridinium chloride are similar to those of chlorhexidine, but CPC stays in the mouth for much shorter periods of time. Its concentration in the oral cavity, compared to that of chlorhexidine, decreases significantly faster within $12 \mathrm{~h}$. To obtain the same efficacy as that of chlorhexidine, CPC should be used twice as frequently. Cetylpyridinium chloride is used as $0.05 \%$ and $0.07 \%$ solutions (36).

$\mathrm{CPC}$ is not used in toothpastes. Adverse effects of using this compound may be irritation and ulceration of the oral mucosa; teeth discoloration and desquamation of the epithelium of the oral mucosa were also reported. In addition, patients complain about burning sensation in the tongue and oral mucosa (5).

\section{Sanguinarine}

Sanguinarine $\left(\mathrm{C}_{20} \mathrm{H}_{14} \mathrm{NO}_{4}\right)$ is a substance of natural origin, obtained from the alcohol extract of powdered rhizome of bloodroot (Sanguinaria canadiensis), and has been used in folk medicine and homeopathy for over a hundred years (31). It shows antibacterial activity by disrupting the formation of the bacterial cell membrane. It also prevents the adhesion of bacterial cells to a growing biofilm, being effective against $98 \%$ dental plaque bacteria (37). In addition, it neutralizes sulfur compounds that cause an unpleasant smell from the mouth ("fetor ex ore") and reduces its intensity (5). Despite strong antibacterial action against dental plaque bacteria, it is not effective against microorganisms conducive to periodontitis, and thus cannot be used to treat the latter condition. Products containing sanguinarine are safe, no adverse effects of its use have been observed. The only reported cases involved a burning sensation in the oral mucosa described by a few users of sanguinarine-based mouthwashes (37).

\section{Triclosan}

Triclosan $\left(\mathrm{C}_{12} \mathrm{H}_{7} \mathrm{Cl}_{3} \mathrm{O}_{2}\right)$ is a synthetic compound with a broad spectrum of antimicrobial activity, being effective against bacteria, fungi, and 
sometimes also viruses. It is used as an ingredient of mouthwashes as, apart from having an antiseptic effect, it is a preservative. At low concentrations, similarly to other phenols, it affects the permeability of the cytoplasmatic membrane, causes the efflux of the cell content and changes in cellular oxygen levels; at higher concentrations, it also causes coagulation and denaturation of proteins. The concentration of triclosan in mouthwashes is ca. $0.3 \%$ (38). As research shows, the maximum inhibitory dilution (MID) against the studied bacterial strains were found to vary in different mouthwashes containing triclosan as an active ingredient. This was probably due to different formulations of the tested products and combining triclosan with other active components, such as copolymers, fluoride, cetylpyridinium chloride, and ethanol. It is believed that, apart from the differences in the formulations, the concentration of triclosan and its interactions with other ingredients, are responsible for the varying effects (39). In 2016, the Food and Drug Administration issued a rule banning triclosan from use in the United States of America (40). It was to be removed from the market on September 6, 2017. It has been shown that triclosan may have a harmful effect on the heart and thyroid gland, by disrupting endocrine homeostasis in the system (41).

\section{Hydrogen peroxide}

Hydrogen peroxide $\left(\mathrm{H}_{2} \mathrm{O}_{2}\right)$ is a chemical compound used to destroy microorganisms. The bactericidal efficacy of hydrogen peroxide is due to the release of monoatomic oxygen in the process of chemical reduction. The enzyme enabling the latter reaction is catalase, present in the cells of both hosts and bacteria. Catalase causes the decomposition of hydrogen peroxide into water and monoatomic oxygen (42).

Antibacterial action of monoatomic oxygen consists of denaturation of microbial proteins, which leads to the destruction of microorganisms. During this chemical reaction, large amounts of gas oxygen are produced, which mechanically removes disrupted microorganisms (43). Hydrogen peroxide at $3 \%$ water solution is a generally available antiseptic. In dentistry, it is used mainly in the therapy of gingivitis and periodontitis (5). In addition, hydrogen peroxide shows a bleaching effect, which makes it a useful ingredient for teeth whitening products (6). Indications to use hydrogen peroxide-based mouthwashes include acute inflammatory conditions of the periodontium, including acute necrotizing ulcerative gingivitis and periodontitis. Hydrogen peroxide proves effective in the treatment of gum inflammations before prosthetic therapy. In the form of water solution (diluted directly before use) or gel (to reduce teeth discoloration), it is recommended for daily use mainly in patients with physical or mental disabilities (6).

Adverse effects of hydrogen peroxide may include hypertrophy of tongue papillae, black hairy tongue, changes in the composition of oral bacterial flora, and increased levels of Candida albicans (6).

\section{Povidone-iodine}

Povidone-iodine (PVP-I) $\left(\mathrm{C}_{6} \mathrm{H}_{9} \mathrm{I}_{2} \mathrm{NO}\right)$ is a chemical compound produced by combining polyvinylpyrrolidone with elemental iodine. $10 \%$ PVP-I solutions, used in dentistry, have antiviral, antibacterial, and antifungal action; They are also effective against protozoa and chlamydia. PVP-I demonstrates antibacterial efficacy against Grampositive and Gram-negative bacteria (44). Its antimicrobial action involves the formation of temporary or permanent pores in the cell membranes of microorganisms (45).

Mouthwashes containing povidone-iodine are highly effective in reducing bacterial plaque and inflammatory conditions of the gum, as well as in alleviating the course of stomatitis (6). Povidoneiodine applied during the procedure of removal of supragingival and subgingival calculus demonstrates high efficacy in reducing inflammation of gum and periodontium. The use of PVP-I solution to rinse gum pockets after removal of supragingival and subgingival deposits helps reduce the size of pathological gum pockets after the procedure (45). Adverse effects of povidone-iodine include temporary discoloration of the teeth and tongue. Due to the presence of elemental iodine in PVP-I, there is also a risk of its negatively influencing the thyroid gland, which is manifested by a slight increase in serum TSH levels and in iodine levels in the blood and urine. PVP-I-based mouthwashes are not recommended to patients allergic to iodine. Mouthwashes containing povidone-iodine are safe to use in patients without thyroid disorders (6).

\section{Delmopinol hydrochloride (decapinol)}

Decapinol $\left(\mathrm{C}_{16} \mathrm{H}_{34} \mathrm{ClNO}_{2}\right)$ is a derivative of morpholine. Chemically, it is a cationic agent at acidic $\mathrm{pH}$. The antibacterial efficacy of this compound is weak, yet it has strong surface activity. Decapinol disrupts physicochemical properties of the oral mucosa and hard surfaces of teeth tissues, preventing adhesion and accumulation of microorganisms (46).

Delmopinol hydrochloride can be used (as a $0.1 \%$ solution) interchangeably with a $0.2 \%$ 
chlorhexidine solution to reduce gum bleeding. Compared to chlorhexidine, delmopinol is markedly less effective in reducing oral microflora and changing its composition (47).

Certain adverse effects of using mouthwashes with delmopinol hydrochloride were reported, such as bitter taste sensation, a burning sensation in the oral mucosa, and a sensation of anesthesia in the surface of the mucosa (31).

\section{Octapinol}

Similarly to delmopinol hydrochloride octapinol $\left(\mathrm{C}_{15} \mathrm{H}_{31} \mathrm{NO}\right)$ is a surface-active agent. As such, it reduces adhesion and accumulation of bacteria and other microorganisms to the surface of the teeth and mucosa (48). However, compared to chlorhexidine digluconate, its antibacterial activity is from 5 to 25 times weaker (5).

\section{Hexetidine}

Hexetidine $\left(\mathrm{C}_{21} \mathrm{H}_{45} \mathrm{~N}_{3}\right)$ is a cationic compound, active against Gram-negative and Gram-negative bacteria, as well as fungi (49). The antimicrobial activity of hexetidine against microorganisms present in the oral cavity is lower or comparable to that of chlorhexidine. The efficacy of hexetidine increases together with its concentration, however, the use of concentrated hexetidine solutions is related to the risk of adverse effects, such as desquamation of the oral mucosa epithelium (50).

\section{Ethyl alcohol}

As a preservative and antiseptic, ethyl alcohol $\left(\mathrm{C}_{2} \mathrm{H}_{5} \mathrm{OH}\right)$ is an ingredient of numerous mouthwashes. Its action on the cells of microorganisms causes protein denaturation and leads to the disintegration of the cell membrane. Alcohol is effective against many species of bacteria, viruses, and fungi. However, it has also numerous adverse effects, such as, among others, ulceration of the oral cavity, pain and burning sensation, and exfoliation of oral mucosa epithelium. Since ethyl alcohol affects the emergence of precancerous conditions, the use of mouthwashes containing this ingredient is not recommended (6).

\section{Substances of natural origin}

Substances of natural origin also find application in oral hygiene, in the treatment of gum diseases, and in fighting cariogenic bacteria. They have been used for thousands of years in folk medicine. They have antibacterial, anti-inflammatory, and cytostatic activity. Pomegranate, common guava bark, nimtree, propolis, holy basil, green tea, sodium hydrogen carbonate, large cranberry, potassium aluminum sulfate may be listed among them (51).

Propolis, or bee glue, is widely used to treat periodontal diseases, both acute and chronic, to accelerate healing of postoperative wounds and ulcers of the oral mucosa. It also slows down the growth of bacteria and bacterial colonization of teeth surfaces, thus inhibiting biofilm development (52).

Mouthwashes containing water solution of sodium hydrogen carbonate are used to reduce dryness in the mouth and prevent teeth erosion. Due to its alkaline $\mathrm{pH}$, it effectively neutralizes the acids present in the mouth which cause erosion. Sodium hydrogen carbonate has anti-caries activity, by increasing the $\mathrm{pH}$ of saliva, which inhibits the growth of acidogenic bacteria, such as $S$. mutans (6). Products with essential oils, such as mint oil, eucalyptus oil, wintergreen oil, and thyme oil, are increasingly used. Essential oils have antibacterial, antifungal, and antiviral activity, reduce inflammations and positively affect regeneration processes. Numerous studies showed anti-caries activity of essential oils (53). Compared to chlorhexidine, they cause fewer adverse effects. They are also more and more frequently used as ingredients of mouthwashes, such as the popular Listerine ${ }^{\circledast}$ (54).

In Poland, Dentosept ${ }^{\oplus}$ by Phyto Pharm is such a well-known and popular product. It is a solution of substances of natural origin used, after diluting it in water, as a mouthwash. It consists of extracts from chamomile flowers, oak bark, arnica leaves, calamus rhizome, mint leaves, thyme leaves, and ethanol (60-70\%) (55). The mentioned substances have antiseptic, astringent, disinfectant, and abirritant effects. Indications to use Dentosept ${ }^{\circledast}$ include gingivitis, oral mucositis, periodontitis, and pressure ulcers in the mouth caused by prosthetic restorations (56).

Products containing substances of natural origin are safe to use, non-toxic for the body. Undesired effects are observed very seldom (53).

\section{Recent clinical trials on the discussed substances}

The results of the study concerning an influence of active ingredients on oral microflora, conducted both on reference strains and under the clinical conditions, differ from each other, however, in the majority they prove that mouthwashes including active ingredients with diversified antimicrobial mechanisms show a wider spectrum of action against bacterial and fungal microflora, responsible for the accumulation of dental plaque than mouthwashes including individual active ingredients. The 
confirmation of that is provided by the review of studies published within the last 5 years.

In the works published in 2018, no positive influence of Listerine ${ }^{\circledR}$ mouthwash (NaF and aminofluoride) on the reduction of $S$. mutans bacteria was found. However, researchers detected a similar impact of Colgate Plax ${ }^{\circledast}$ and Oral $\mathrm{B}^{\circledast}$ (both including $\mathrm{NaF}$ and $\mathrm{CPC}$ ) on the reduction of the number of $S$. mutans bacteria (57). This finding is similar to the previous results obtained by Cardoso et al. against $S$. mutans reference strains (58).

Also, the Listerine ${ }^{\circledast}$ mouthwash did not positively influence the reduction of $C$. albicans yeasts, while the above-mentioned mouthwashes containing sodium fluoride and cetylpyridine chloride had an impact on the reduction of $C$. albicans strains (57).

Authors of the works published in 2017 indicate a greater antimicrobial influence of the mouthwash containing sodium fluoride and chlorhexidine on L. acidophilus bacteria than the mouthwash including only sodium fluoride, however, in the case of $S$. mutans bacteria, a greater reduction in its number was achieved with a mouthwash containing only sodium fluoride as an active ingredient and not in the case of a mouthwash involving two mentioned active ingredients (59).

It was also proved that a mouthwash with sodium fluoride and chlorhexidine effectively reduced the number of reference strains of $C$. albicans yeasts (60).

Colgate Plax ${ }^{\circledast}$ and Oral B Pro-Expert ${ }^{\circledast}$ mouthwashes including sodium fluoride and cetylpyridine chloride inhibited the growth of $C$. albicans reference strains in the zone of similar diameter (61) as in the previous studies (62).

The results, published in 2015, of the research on antimicrobial effectiveness of active ingredients of mouthwashes are the following: When evaluating a mouthwash including sodium fluoride and cetylpyridine chloride as active ingredients, there obtained $100 \%$ reduction of bacteria in oral bacterial biofilm, while after the use of mouthwash involving only $\mathrm{NaF}$, the number of $S$. mutans present in dental plaque was reduced by only $16.82 \%$ (63). While evaluating the efficacy of various antibacterial substances against $S$. mutans grown on the readymade enamel slabs, Salvas et al. observed that a mouthwash containing sodium fluoride and cetylpyridine chloride was one of the most effective in the reduction of the quantity of $S$. mutans colonies (64). Evans et al. compared the antimicrobial influence of mouthwashes containing individual active ingredients - sodium fluoride in the concentration of
$0.05 \%$ (Colgate Neutrafluor $220^{\circledast}$ ) and cetylpyridinium chloride in the concentration of $0.05 \%$ $\left(\mathrm{Cepacol}^{\circledR}\right)$ on reference S. mutans L. and acidophilus strains. It was found out that the inhibition zone was respectively equal to $7.5 \mathrm{~mm}$ for $S$. mutans and $12 \mathrm{~mm}$ for L. acidophilus in the case of mouthwash with sodium fluoride, and respectively $8.6 \mathrm{~mm}$ and $11.1 \mathrm{~mm}$ - with Candida. Each of the active ingredients separately showed similar antibacterial properties (65).

The mere presence of fluorine as an active ingredient in a mouthwash does not significantly influence the reduction of $S$. mutans strains in comparison with a mouthwash containing chlorhexidine and fluorine, which was proved by evaluating the influence of mouthwashes with various ingredients on recently extracted maxillary premolars. In this case, also synergistic antibacterial activity of chlorhexidine and fluorine against $S$. mutans was confirmed (66).

\section{CONCLUSIONS}

Inhibition of the growth and metabolism of bacteria, inhibition of bacterial colonization, modification of biochemical processes, and disrupting the structure of mature dental plaque, belong among different mechanisms underlying the efficacy of active ingredients of mouthwashes and are key elements in caries and periodontal prophylactics, as well as support the treatment of gum and periodontium diseases $(67,68)$.

\section{Acknowledgment}

The study was financed as part of the statutory activity of the Medical University of Lublin, Poland (grant number: DS 290).

\section{Conflict of interests}

The authors declare that they have no conflict of interests.

\section{REFERENCES}

1. Shibly O., Rifai S., Zambon J.J.: Periodontol. 2000 8, 42 (1995).

2. Marsh P.D., Moter A., Devine D.A.: Periodontol. 2000 55, 16 (2011).

3. Dolińska E., Skurska A., Paniczko-Drężek A., Pietruska M., Stokowska W.: Czas. Stomatol. 62, 478 (2009) (in Polish).

4. Oyanagi T., Tagami J., Matin K.: Open Dent. J. 6, 23 (2012). 
5. Galińska B.: Forum Stomatol. 2, 43 (2004) (in Polish).

6. Farah C.S., McIntosh L., McCullough M.J.: Aust. Prescr. 32, 162 (2009).

7. Tartaglia M., Tadakamadla S.K., Connelly S.T., Sforza C., Martín C.: Ther. Adv. Drug Saf. 10, 1 (2019).

8. DePaola L.G., Spolarich A.E.: J. Dent. Hyg. 81 (Suppl. 1), 13 (2007).

9. Sykes L.M., Comley M., Kelly L.: S. Afr. Dent. J. 71, 308 (2016).

10. Parashar A.: Sch. J. Dent. Sci. 2, 186 (2015).

11. Cortelli S.C., Costa F.O., Rode S.M., Haas A.N., Andrade A.K.P. et al.: Braz. Oral Res. 28, 1 (2014).

12. Rathore K.K., Reddy H.G., Johar R.S., Kadelwal P., Shetty R.M. et al.: Indian J. Dent. Oral Health. 2, 1 (2018).

13. Markowitz K.: J. Dent. 41, S1 (2013).

14. Karale S., Chandak S., Moon A., Singh P., Atulkar M. et al.: Int. J. Oral Health Med. Res. 3, 71 (2017).

15. Kaczmarek U., Kłaniecka B.: Dent. Med. Probl. 50, 441 (2013).

16. Kaczmarek U., Jackowska T., MielnikBłaszczak M., Jurczak A., Olczak-Kowalczyk D.: Nowa Stomatol. 24, 70 (2019) (in Polish).

17. Raja M., Saha S., Reddy V.K., Mohd S., Kumari M.: Int. J. Oral Health Res. Rev. 1, 24 (2013).

18. Kaczmarek U.: Czas. Stomatol. 60, 88 (2007) (in Polish).

19. Potting C.M.J., Uitterhoeve R., Scholte Op Reimer W., Van Achterberg T.: Eur. J. Cancer. Care. 15, 431 (2006).

20. Pedrazzi V., Escobar E.C., Cortelli J.R., Haas A.N., Andrade A.K.P., et al.: Braz. Oral Res. 28, 1 (2014).

21. Li K.Q., Jia S.S., Ma M., Shen H.Z., Xu L.: Braz. J. Med. Biol. Res. 49, e5291 (2016).

22. Rugg-Gunn A.: Acta Med. Acad. 42, 117 (2013).

23. Lussi A., Hellwig E., Klimek J.: Schweiz. Monatsschr. Zahnmed. 122, 1030 (2012).

24. Hong J.Y., Lim H.Ch., Herr Y.: J. Periodontal Implant Sci. 46, 45 (2016).

25. Falcâo A., Masson N., Leitâo J.N., Botelho J.N.: Braz. Oral Res. 30, 1 (2016).

26. https://www.researchgate.net/publication/267099100_In_situ_antimicrobial_activity_of_chlorhexidine_in_the_oral_cavity (accessed on 01.03.2020)

27. Balagopal S., Arjunkumar R.: J. Pharm. Sci. Res. 5, 270 (2013).
28. Gomes B.P.F.A., Vianna M.E., Zaia A.A., Almeida J.F.A., Souza-Filho F.J., et al.: Braz. Dent. J. 24, 89 (2013).

29. Abouassi T., Hannig Ch., Mahncke K., Karygianni L., Wolkewitz M., et al.: BMC Res. Notes 7, 711 (2014).

30. Humbire C.U.: J. Int. Soc. Prev. Community Dent. 5, 218 (2015).

31. Tanasiewicz M., Twardawa H.: Twój Prz. Stomatol. 7-8, 54 (2011) (in Polish).

32. Dąbrowska E., Balunowska M., Letko M., Borkowska-Chwieśko A., Letko R.: Ann. UMCS Sect. D 60 (Suppl.), 333 (2005).

33. Malicka B., Ziętek M., Grzebieluch W.: Dent. Med. Probl. 42, 497 (2005) (in Polish).

34. Wassif Haq M., Batool M., Hammad Ahsan S., Sharma G.: Gen. Dent. 5-6, 110 (2011).

35. Latimer J., Munday J.L., Buzza K.M., Forbes S., et al.: BMC Microbiol. 15, 169 (2015).

36. Rahman B., Alkawas S., Zubaidi E., Adel O., Hawas N.: Contemp. Clin. Dent. 5, 466 (2014).

37. Silveira Moretti A.B., Camargo Abdo R.C., Tavares Carvalho J.C., Andrade Moreira Machado M.A., Silva S.M.B.: Open Compl. Med. J. 1, 97 (2009).

38. Izydorczak M., Stefańska J.: Biul. Wydz. Farm. 2, 13 (2007) (in Polish).

39. Tanomaru J.M.G., Nascimento A.P., Watanabe E., Matoba-Júnior F., Tanomaru-Filho M. et al.: Braz. J. Microbiol. 39, 569 (2008).

40. https://www.fda.gov/news-events/pressannouncements/fda-issues-final-rule-safetyand-effectiveness-antibacterial-soaps (accessed on 26.05.2020).

41. Zorrilla L.M., Gibson E.K., Jeffay S.C., Crofton K.M., Setzer W.R.: Toxicol. Sci. 107, 56 (2009).

42. Brudzynski K., Abubaker K., St-Martin L., Castle A.: Front. Microbiol. 2, 213 (2011)

43. Miyasaki K.T., Genco R.J., Wilson M.E.: J. Dent. Res. 65, 1142 (1986).

44. Gefrerer M., Janicha J., Olczak-Kowalczyk D.: Dent. Forum. 42, 65 (2014) (in Polish).

45. Amin M.S., Harrison R.L., Benton T.S., Roberts M., Weinstein P.: Ped. Dent. 26, 5 (2004).

46. Freitas-Fernandes L.B., Rundegren J., Arnebrant T., Glantz P.: Braz. Dent. J. 12, 173 (2001).

47. Soares Luís H., Soares Luís L., Bernardo M., Nascimento I.: J. Dent. Sci. 4, 52 (2016).

48. Willard L.O., Edwardsson S., Attström R., Matsson L.: J. Periodontal Res. 18, 429 (1983).

49. Aoun G., Saadeh N., Berberi A.: J. Int. Oral Health. 7, 5 (2015). 
50. Himratul-Aznita W.H., Fathilah A.R.: J. Med. Sci. 6, 59 (2006).

51. Kukreja B.J., Dodwad V.: Int. J. Pharm. Bio. Sci. 3, 46 (2012).

52. Pereira E.M.R, Candido da Silva J.L.D., Silva F.F.S., De Luca M.P., et al.: Evid. Based Complement. Alternat. Med., Article ID 750249, 7 pages (2011).

53. Quintas V., Prada-Lopez I., Donos N., SuarezQuintanilla D., Inmaculada T.: PloS One 10, E0117177 (2015).

54. Kwiatkowska A., Mielczarek A., Gajewski T.: Nowa Stomatol. 22, 148 (2017) (in Polish).

55. Kędzia A., Wierzbowska M., Kufel A.: Post. Fitoter. 1, 2 (2007) (in Polish).

56. Gerreth K., Borysewicz-Lewicka M.: Dent. Forum 37, 45 (2009) (in Polish).

57. Oliveira J.R., Belato K.K., Oliveira F.E., Cardoso Jorge A.O, Camargo S.E.A., et al.: Gen. Dent. 66, 28 (2018).

58. Cardoso T.R., Cavalho A.S, Beletti M.E., Napimoga M.H.m Thedei G.: Braz. J. Oral Sci. 10, 74 (2011).

(c) 2020 by Polish Pharmaceutical Society. This is an access article under the CC BY NC license

\footnotetext{
2020 by Polish Pharmaceutical Society. This is an access article under the CC
(http://creativecommons.org/licenses/by-nc/4.0/).
}

59. Ximenes M., Cardoso M., Astroga F., Arnold R., Pimenta L.A. et al.: Braz. Oral Res. 31, 1 (2017).

60. Paulone S., Malavasi G., Arizzoni A., Orsi C.F., Peppologi A.: New Microbiol. 40, 45 (2017).

61. Moroz J., Kurnatowski P.: Ann. Parasitology 63, 331 (2017).

62. Talebi S., Sabokar A., Riazipour M., Saffari M.: J. Microbiol. 7, 1 (2014).

63. Yang S.J., Han S.H., Lee A.R., Jun J.H., Son M.W., et al.: BMB Rep. 48, 42 (2015).

64. Savas S., Kucukyilmaz E., Clik E.C., Ates M.: J. Oral Sci. 57, 367 (2015).

65. Evans A., Leishma S.J., Walsh L.J., Seow W.K.: Austr. Dent. J. 60, 247 (2015).

66. Jazaeri M., Pakdel F., Rezael-Soufi L., Abdolsamadi H.: J. Dent. Res. Dent. Clin. Dent. Prospects 9, 44 (2015).

67. Próchnica zębów. Choroba próchnicowa i postępowanie kliniczne. Fejerskov O., Kidd E. Kaczmarek U. Eds., Wydawnictwo Urban \& Partner, Wrocław 2006. (in Polish).

68. Górska R., Konopka T.: Periodontologia współczesna, Med. Tour Press, Warszawa 2013 (in Polish). 